\title{
On the Characterization of Dredged Marine Soils from Malaysian Waters: Physical Properties
}

\author{
Zarina Shahri ${ }^{1} \&$ Chee-Ming Chan ${ }^{2}$ \\ ${ }^{1}$ Faculty of Civil and Environmental Engineering, Universiti Tun Hussein Onn Malaysia, Johor, Malaysia \\ ${ }^{2}$ Department of Civil Engineering Technology, Faculty of Engineering Technology, Universiti Tun Hussein Onn \\ Malaysia, Johor, Malaysia \\ Correspondence: Zarina Shahri, Faculty of Civil and Environmental Engineering, Universiti Tun Hussein Onn \\ Malaysia, 86400 Parit Raja, Batu Pahat, Johor, Malaysia. Tel: 60-17-725-6252. E-mail: zarinashahri@gmail.com
}

Received: February 15, 2015 Accepted: February 27, 2015 Online Published: May 14, 2015

doi:10.5539/ep.v4n3p1 URL: http://dx.doi.org/10.5539/ep.v4n3p1

\begin{abstract}
Every year, large volumes of dredged marine soils (DMS) are removed from Malaysian water. Dredging activity is needed to maintain and enlarge water bodies. DMS properties are varies depending to space, time and land uses in the watershed. DMS were also reported to be contaminated with chemical and biological contaminants, making the materials risky for reuse. Information on DMS properties, e.g. physical, chemical and biological properties is essential to the selection of a suitable reuse option. This study is focused on the characterization of Malaysian DMS for beneficial reuse. Three samples from different dredging sites and one sample of sediment as a control were used in this study. Physical properties of DMS from Malaysia water were identified and quantified. The DMS were classified as high plasticity clay $(\mathrm{CH})$, high plasticity silt $(\mathrm{MH})$ and low plasticity silt (ML) for Lumut, Melaka and Tok Bali respectively. The results showed that the DMS from different locations have different physical properties. Thus, the characterizations of DMS with regards of physical properties are significant in decision making either to be reused or disposed.
\end{abstract}

Keywords: beneficial reuse, dredged marine soil, dredging, physical properties

\section{Introduction}

Dredging is important to remove materials from the bottom of rivers, harbours and other water bodies. Dredging activities are needed to maintain or enlarge river and port channel, flood control, waterfront construction and access to harbours (Dubois, Abriak, Zentar, \& Balivy, 2009). Sediment is materials that settle at the bottom of a water body. It principally derives from natural processes (e.g. erosion of soil and weathering of rock) and anthropogenic activities (e.g. agricultural practices and construction activities). The term dredged marine soils refers to the sediment that has been dredged from a water body (Permanent International Association of Navigation Congress [PIANC], 2006). Dredged marine soils (DMS) are predominantly clean and usable products. It can be used for beach nourishment, wetland restoration, construction material and wildlife habitat development. However, DMS were also reported to be contaminated with chemical and biological contaminants, which make pre-assessment necessary prior to reuse or disposal.

DMS which are products of dredging activities consist mainly of clays, silts and sands mingled with rocks, debris, larger obstacles and organic matter (Millrath, Kozlova, Meyer, \& Shimanovich, 2002). Organic matter usually derives from humus, decomposed plant, animal residues and other organic matter such as algae, worms and amphipods that settle at the bottom of water's body. According to Torres et al. (2009), for instance decision on the dredging methods, DMS beneficial uses, disposal or treatment options and environmental effects are based on the DMS characteristics. In dredged marine soil management, information on DMS properties, (e.g. physical, chemical and biological properties) are essential to the selection of a suitable DMS management option (Harrington \& Smith, 2013).

Dredged marine soils properties are different with space, time and closely to the past and present land uses in the watershed (Pebbles \& Thorp, 2001 and Mulligan, Yong \& Gibbs, 2001). Dredging location will strongly affect the mineralogy, morphology and composition of the dredged marine soils. Dredged marine soils are heterogeneous and can be characterized by grain size distribution, density, water and organic matter contents 
(Mulligan et al., 2001). In general, dredged marine soils are microcrystalline in nature. Clay minerals like chlorite, kaolinite and illite and non-clay minerals like quartz and feldspar are present in the soils (Rao, Anusha, Pranav, \& Venkatesh, 2012).

DMS had been reused in various industries based on the soils properties (e.g. brick and tile making, cement production, beach nourishment, land reclamation, landfill cover and wetland restoration). Particle size is one of the main key physical properties of the material to be used. According to US Environmental Protection Agency (USEPA) \& US Army Corps of Engineers (USACE) (2004), sand remains the most favorable suitable material for beach nourishment. Harrington \& Smith, (2013) reported that a mixture of both coarse and fine-grained, of low moisture and clay contents with low permeability are the properties of material to be used for landfill cover. In bricks and ceramic making, soils contained 10-50\% of clay fraction with some presence of silt and sand are accepted be used (International Labour Office, 1984). The objective of this study is to characterize DMS sample as pre-assessment for reuse or disposal.

\section{Method}

The disturbed DMS were collected from Lumut (Perak), Marina Melaka (Melaka), Tok Bali (Kelantan) and Pasir Gudang (Johor) (Figure 1). The sample was dredged by trailing suction hopper dredger (TSHD) at a depth of 8-12 $\mathrm{m}$ from sea level (Figure 2(a)) for Lumut site. The marine soils from Marina Melaka were dredged by backhoe dredger (BHD) at a depth of 3.5 - $6.5 \mathrm{~m}$ from sea level (Figure 2(b)). Backhoe dredger was also used at Tok Bali to dredge the marine soils at depth 3.5 - 5.0 m from sea level. Sample from Pasir Gudang site was taken from $0-10 \mathrm{~cm}$ of the sediment surface. Figure 3 shows DMS sample. The DMS samples were put in sealed plastic bags to prevent moisture loss. Once the samples arrived at geotechnical laboratory, all the samples in the plastic bags were transferred to covered tank for storage.

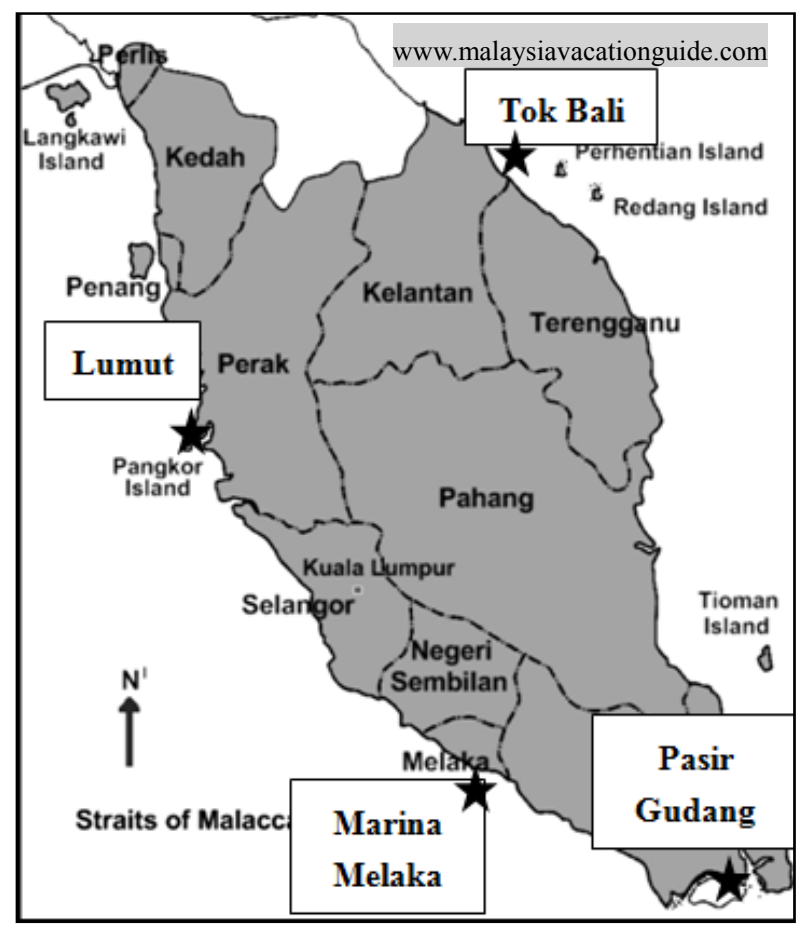

Figure 1. Location map of sampling sites ( $\lambda \bar{\top}$ sampling site) 


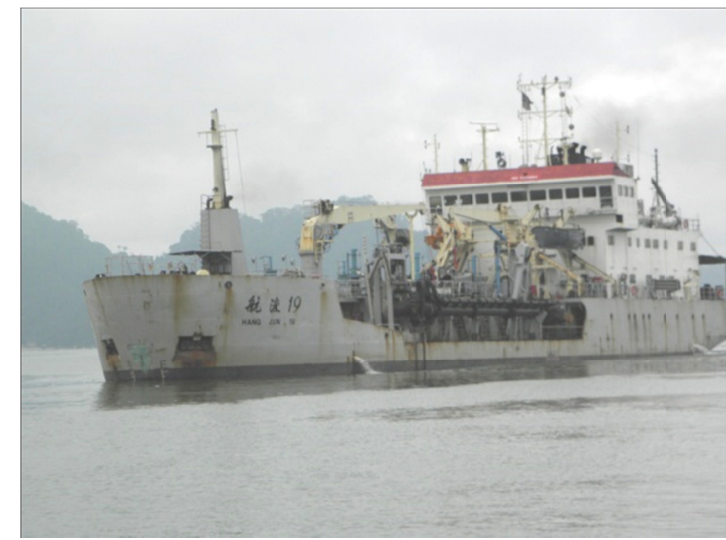

a) Trailing suction hopper dredger (TSHD)

(Lumut, Perak)

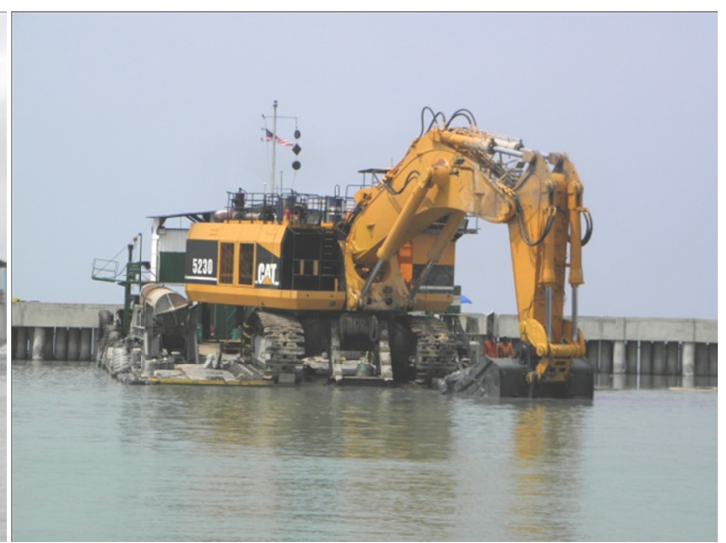

b) Backhoe dredger (BHD)

(Marina Melaka, Melaka)

Figure 2. Dredger

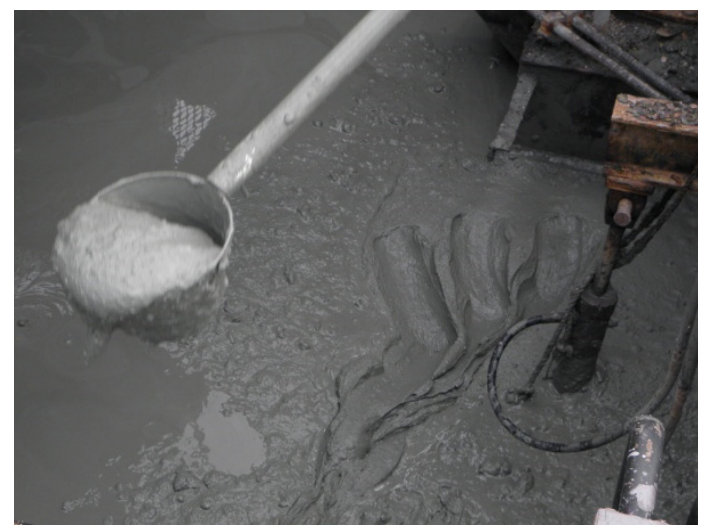

Figure 3. Dredged marine soils

All the physical properties tests were carried out primarily based on the procedures given in British Standard (BS1377: 1990). The particle sizes were measured by wet sieving and continued with hydrometer analysis. Oven dried method was used for moisture content test. Atterberg limits test covered liquid limit test and plastic limit test. Liquid limit test was determined by fall cone method. The specific gravity was determined by using small pyknometer method. Distilled water is normally used as the density bottle fluid; however an alternative liquid (i.e. kerosene and white spirit) should be used if the soil contains soluble salts.

\section{Results and Discussion}

\subsection{Particle Size Distribution}

Soils are generally called gravel, sand, silt or clay depending on the predominant size of particles within the soil. Based on American Association of State Highway and Transportation Officials (AASHTO) (2008), as shown in Table 1, gravel grain size is $76.2 \mathrm{~mm}$ to $2 \mathrm{~mm}$, sand grain size is $2 \mathrm{~mm}$ to $0.075 \mathrm{~mm}$, silt grain size is $0.075 \mathrm{~mm}$ to $0.002 \mathrm{~mm}$ and grain size less than $0.002 \mathrm{~mm}$ is clay. The particle size distribution indicated that clay is the main particle of all samples in this study except for Pasir Gudang (Figure 4). The results also showed that three quarter of the samples are fine particles. The Lumut sample contained the highest clay particle i.e. $78 \%$, Melaka, $68 \%$, Tok Bali, $60 \%$ and the Pasir Gudang sample contained the least percentage of clay, $26 \%$. Sand portion for Lumut and Tok Bali sample is higher than silt portion. It was different with Melaka and Pasir Gudang sample where silt portion was higher than sand portion. Silt portion of Pasir Gudang sample also was greater than clay portion. The curve of Pasir Gudang showed between $0.063 \mathrm{~mm}$ to $0.048 \mathrm{~mm}$ because there is no particle in the range size.

This was supported by others finding (Table 1) that most of DMS contain high fine particles (silt and clay) compared to gravel and sand particles. It was different with Kuala Perlis dredged soils by Wan Salim et al. 
(2012), where sand portion was higher compared to fine particles portion. The activities near the sampling area contribute to different particle size distribution of the sample. The percentage of silt and sand particles for the Lumut sample are lower compared to those of Melaka and Tok Bali. The sampling location of Lumut sample was offshore, while Melaka and Pasir Gudang sample collection points were near to shore. The Tok Bali sample was retrieved near to the river mouth. The location of sampling site influenced the dredged marine soil properties. The sedimentation process would transport large particles near the shore (Mulligan, Fukue, \& Sato, 2010). The highest contents of silt and sand particles in Tok Bali sample could be traced back to the mining activities at nearby Sungai Semerak, Tok Bali.

Table 1. Comparison of particle size distribution of dredged marine soils

\begin{tabular}{|c|c|c|c|c|}
\hline \multirow[t]{2}{*}{ Particle Size Distribution (\%) } & \multicolumn{4}{|c|}{$\begin{array}{c}\text { American Association of State Highway and } \\
\text { Transportation Officials (AASHTO) }\end{array}$} \\
\hline & Gravel & Sand & Silt & Clay \\
\hline Lumut* & 3 & 15 & 4 & 78 \\
\hline Melaka* & 3 & 9 & 20 & 68 \\
\hline Tok Bali* & 5 & 20 & 15 & 60 \\
\hline P.Gudang* & 2 & 18 & 54 & 26 \\
\hline Visakhapatnam, India (Basack \& Purkayastha, 2009) & - & 14 & 27 & 59 \\
\hline $\begin{array}{l}\text { Craney Island (Grubb, Chrysochoou, Smith, \& Malasavage, } \\
\text { 2010) }\end{array}$ & - & 13 & 23 & 64 \\
\hline Osaka, Japan (Chan,Mizutani, Kikuchi, \& Kawabata, 2011) & - & 3 & \multicolumn{2}{|c|}{97 (Fine particles) } \\
\hline Dunkerque, France (Miraoui, Zentar, \& Abriak, 2012) & - & 2.5 & 80 & 8.5 \\
\hline Kuala Perlis, Malaysia (Wan Salim et al., 2012) & - & 44.8 & 34.7 & 20.5 \\
\hline $\begin{array}{l}\text { Dunkirk, France (Zentar, Wang, Abriak, Benzerzour, \& Chen, } \\
\text { 2012) }\end{array}$ & - & 10.8 & 74.7 & 14.5 \\
\hline
\end{tabular}

*In this study

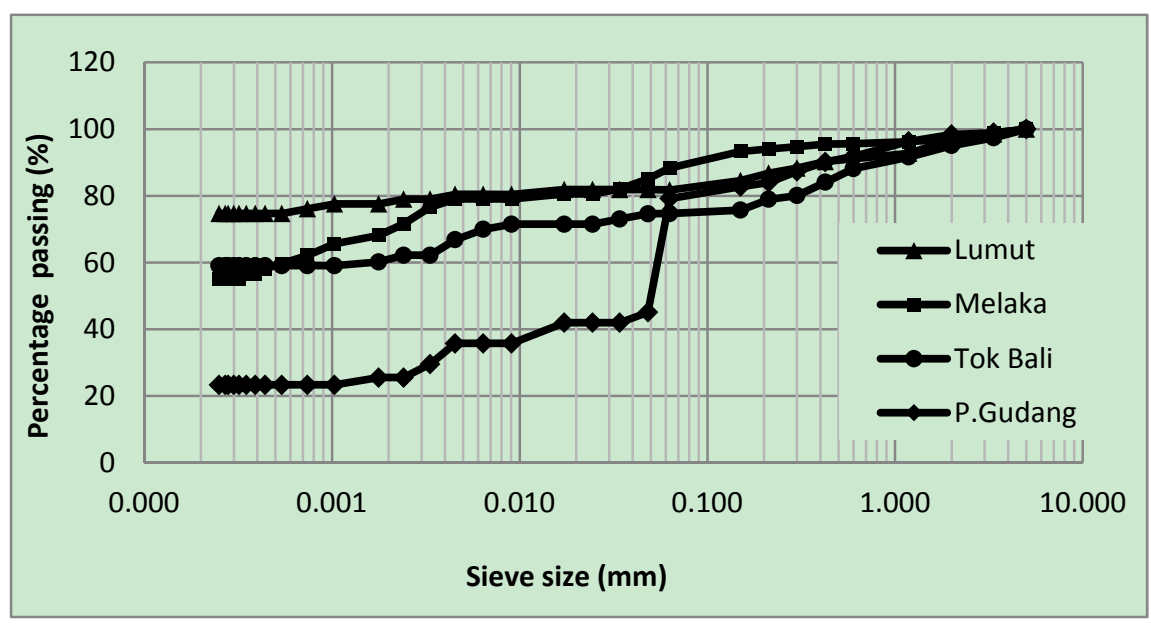

Figure 4. Particle size distribution

\subsection{Specific Gravity $\left(\mathrm{G}_{\mathrm{s}}\right)$}

The specific gravity $\left(\mathrm{G}_{\mathrm{s}}\right)$ of Lumut, Melaka, Tok Bali and Pasir Gudang samples were 2.60, 2.63, 2.38 and 2.41. The results were compared with previous studies (Table 2). The $\mathrm{G}_{\mathrm{s}}$ of Lumut and Melaka samples were in agreement with measured by Basack \& Purkayastha (2009), with ranged between 2.60 to 2.63. According to 
Mulligan et al. (2010), dredged marine soil particles with high specific gravity would settle faster compared to those with low specific gravity. Hence, Tok Bali and Pasir Gudang samples can be declared to have lower $\mathrm{G}_{\mathrm{s}}$ compared to Lumut and Melaka samples. The specific gravity value depends on the particle size of the sample.Figure 6 shows the relationship of fine particle and specific gravity. Specific gravity increased with fine particles. The $\mathrm{G}_{\mathrm{s}}$ of DMS could also be affected by soil mineral (Das, 2013). Common minerals found in soils have specific gravity range of 2.6-2.9. The $\mathrm{G}_{\mathrm{s}}$ of mineral found in DMS such as illite, montmorillonite, chlorite and kaolinite were $2.8,2.65-2.80,2.6-2.9$ and 2.6 respectively.

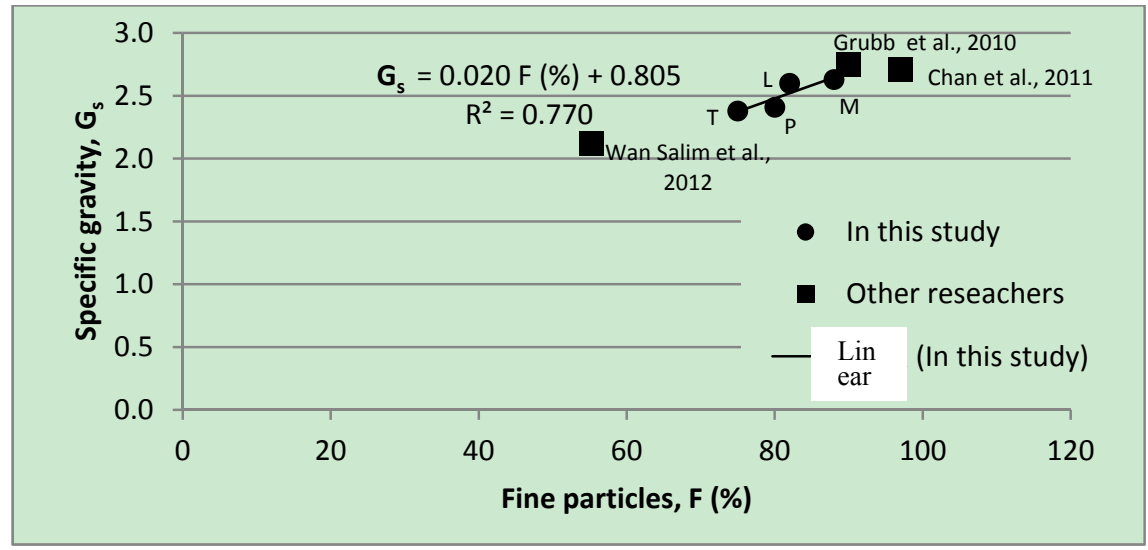

Figure 5. Correlation between specific gravity and fine particles percentage

Table 2. Specific gravity of dredged marine soils

\begin{tabular}{lc}
\hline Sample & Specific gravity, $\mathrm{G}_{\mathrm{s}}$ \\
\hline Lumut* & 2.60 \\
Melaka* & 2.63 \\
Tok Bali* & 2.38 \\
PasirGudang* & 2.41 \\
Visakhapatnam, India (Basack \& Purkayastha, 2009) & 2.62 \\
Craney Island (Grubb et al., 2010) & 2.75 \\
Osaka, Japan (Chan et al., 2011) & 2.71 \\
BatuPahat, Malaysia (Mohd Yusoff, 2011) & 2.48 \\
Kakinada, India (Rao et al., 2011) & 2.35 \\
Kuala Perlis, Malaysia (Wan Salim et al., 2012) & 2.15 \\
\hline * In this study
\end{tabular}

\subsection{Moisture Content (w)}

The moisture content of samples from Lumut, Melaka, Pasir Gudang and Tok Bali are $166.16 \%, 145.77 \%$, $122.29 \%$ and $92.23 \%$ respectively (Table 3 ). The highest moisture content of dredged marine soils by other researchers were $225.00 \%$ by Meegoda \& Perera (2001) and followed by Miraoui et al. (2012) with $181.00 \%$ of moisture content. Figure 6 shows the relationship between fine particles (silt and clay) and the moisture content of the soils. Based on the results, the moisture content showed positive correlation with fine particles. Winfield \& Lee (1999) noted that the moisture content is influenced by soil particles. These finding is similar with Kuala Perlis DMS, where the moisture content is low $(66.13 \%)$ due to less fine particles compared to others studied (Wan Salim et al., 2012). The dredged marine soil has the ability to retain water due to arrangement of the soil particles. The pores between the soil particles were filled with air and water. The water molecules are attracted to one another and are inclined to stack over one. They also hold on more tightly to fine particles compared to sand (Das, 2013).

Interaction between clay, water and electrolytes resulted of difussed double layer. Negative charges in dry clay are balanced by exchangeable cation. However, when water is added to clay, the cations and a small number of 
anions float around the clay particles. Water molecules stand of hydrogen atoms and oxygens atom. Hydrogen atoms are bonded with oxygen atom at an angle of $105^{\circ}$. As a results, the hydrogen atoms acts like a small rod with positive charge at one end and negative charge at the other end. It is known as dipole. The dipolar water was attracted both by the negative charge of the clay and the cation in the double layer. The cations, in turn are attracted to the soil particles (Das, 2013).

Table 3. Comparison of moisture content of dredged marine soils

\begin{tabular}{lr}
\hline Sample/Work & Moisture content, $w(\%)$ \\
\hline Lumut* & 166.16 \\
Melaka* & 145.77 \\
Tok Bali* & 92.23 \\
PasirGudang* & 122.29 \\
New York, United State (Meegoda \& Perera, 2001) & 225.00 \\
Craney Island (Grubb et al., 2010) & 117.00 \\
Osaka, Japan (Chan et al., 2011) & 124.40 \\
Kakinada, India (Rao et al., 2011) & 96.15 \\
Dunkerque, France (Miraouiet al., 2012) & 181.00 \\
Kuala Perlis, Malaysia (Wan Salim et al., 2012) & 66.13 \\
\hline
\end{tabular}

*In this study

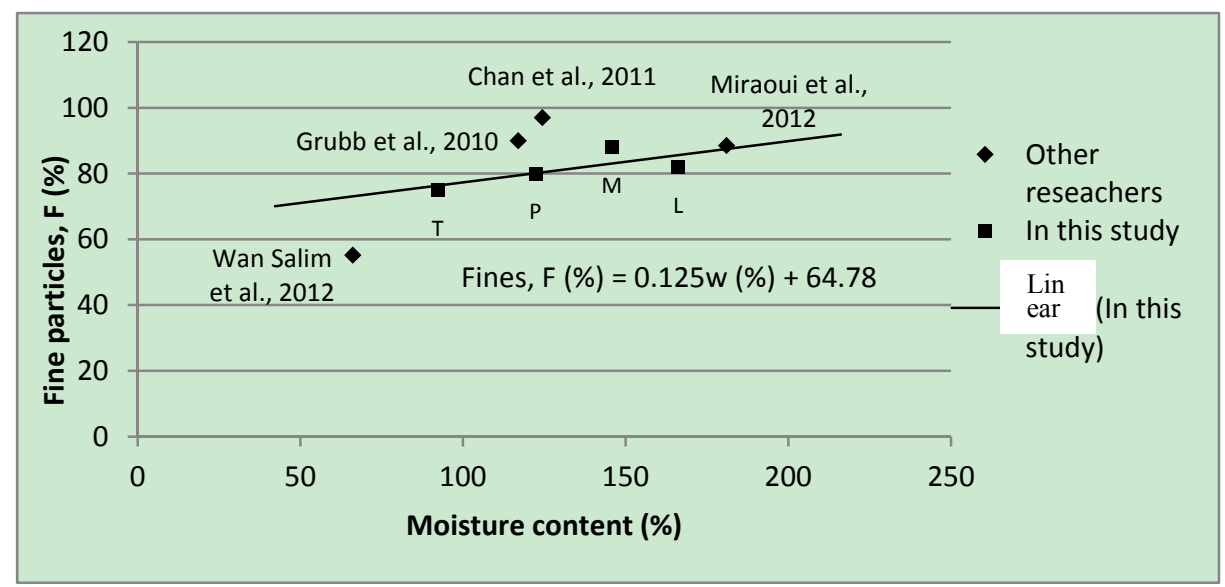

Figure 6. Correlation between fine particles and moisture content

\subsection{Atterberg Limits}

For Atterberg limits of the dredged marine soils, the liquid limit $\left(\mathrm{w}_{\mathrm{L}}\right)$ of Lumut, Melaka, Tok Bali and Pasir Gudang samples were $95.80 \%, 58.50 \%, 36.80 \%$ and $46.10 \%$ respectively. The soils were categorized as high plasticity $(\mathrm{H})$ when the liquid limit was more than $50 \%$ and low plasticity (L) if liquid limit less than $50 \%$. The plastic limit of Lumut, Melaka, Tok Bali and Pasir Gudang were 34.50\%, 30.72 \%, $25.83 \%$ and $35.60 \%$. Plasticity index $\left(\mathrm{I}_{\mathrm{P}}\right)$ of Lumut sample was highest among the four samples $(61.30 \%)$ and followed by Melaka sample, $23.48 \%$. The PI of Tok Bali and Pasir Gudang were $10.97 \%$ and $10.50 \%$. In plasticity chart (Figure 7), $\mathrm{I}_{\mathrm{P}}$ plot is above A-line and indicated as $\mathrm{CH}$ group for Lumut sample. Based on plasticity chart, Melaka sample is in the $\mathrm{MH}$ group while Tok Bali and Pasir Gudang sample is in ML group as plotted below the A-line. $\mathrm{CH}$ indicates high plasticity clay, MH means high plasticity silt and ML represents low plasticity silt. Figure 8 shows the correlation between plastic limit $\left(\mathrm{w}_{\mathrm{P}}\right)$ and clay. The $\mathrm{w}_{\mathrm{P}}$ is ranged between 25.83 to $35.60 \%$ while the clay was $26 \%$ to $78 \%$. Even though clay portion of Lumut samples greater than others samples, its $\mathrm{w}_{\mathrm{P}}$ value is lower than Melaka and Pasir Gudang values. 


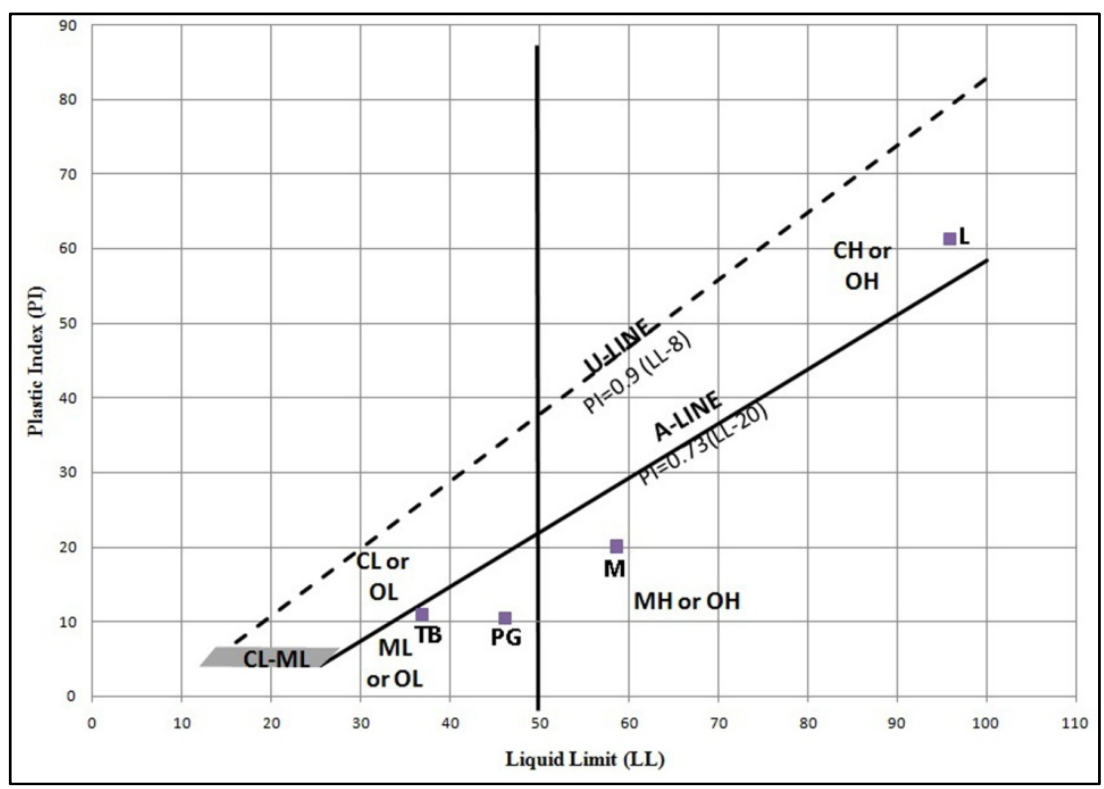

Figure 7. Plasticity chart $(\mathrm{TB}=$ Tok Bali, $\mathrm{M}=$ Melaka, $\mathrm{L}=$ Lumut, $\mathrm{PG}=$ Pasir Gudang)

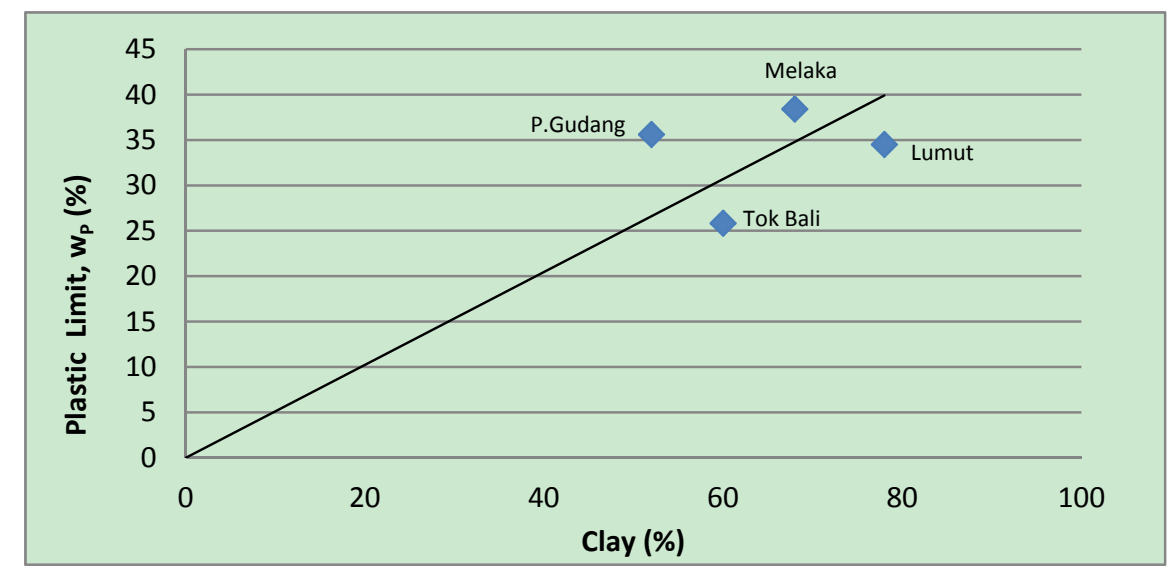

Figure 8. Comparison between plastic limit and clay portion

\subsection{Comparison with Other Soils}

Dredged marine soils properties are different with space and time and are closely related to the past and present land uses in the watershed (Pebbles \& Thorp, 2001 and Mulligan et al., 2001).Dredging location could affect the mineralogy, morphology and composition of the dredged marine soils too. Dredged marine soils are heterogeneous and can be characterized by grain size distribution, density, water and organic matter contents (Mulligan et al., 2001). Table 7 shows the dredged marine soils properties from several published works. 
Table 7. Dredged marine soil properties

\begin{tabular}{lcccccc}
\hline \multirow{2}{*}{ References } & Types of soil & $\begin{array}{c}\text { Moisture } \\
\text { Content } \\
(\%)\end{array}$ & $\begin{array}{c}\text { Specific } \\
\text { Gravity, } \\
\mathrm{G}_{\mathrm{s}}\end{array}$ & $\begin{array}{c}\text { Liquid } \\
\text { Limit, } \\
\mathrm{w}_{\mathrm{L}}(\%)\end{array}$ & $\begin{array}{c}\text { Plastic } \\
\text { Limit, } \\
\mathrm{w}_{\mathrm{P}}(\%)\end{array}$ & $\begin{array}{c}\text { Plasticity } \\
\text { Index, } \mathrm{I}_{\mathrm{P}} \\
(\%)\end{array}$ \\
\hline Basack \& Purkayastha (2009) & Marine clay & - & 2.62 & 89.00 & 47.00 & 42.00 \\
Grubb et al. (2010) & Dredged marine soil & 117.00 & 2.75 & 62.00 & 26.00 & 39.00 \\
Rao et al. (2011) & Marine clay & 96.15 & 2.35 & 84.58 & 45.69 & 38.89 \\
Chan et al. (2011) & Dredged Osaka clay & 124.40 & 2.71 & 113.50 & 43.50 & 70.00 \\
Mohd Yusoff (2011) & Marine clay 1 & 55.04 & 2.48 & 48.12 & 22.70 & 25.42 \\
& Marine clay 2 & 72.47 & 2.26 & 50.40 & 35.60 & 14.80 \\
\hline
\end{tabular}

\section{Conclusion}

The present study has shown that the DMS have difference physical characteristics from different dredging sites. The DMS are not significantly dissimilar with common soils with exception of chemical and biological contaminants. All the physical properties correlations are to ascertain safety and suitability for certain beneficial reuse. Thus, the characterizations of DMS with regards of physical properties are significant in decision making either to be reused or disposed.

\section{Acknowledgments}

Thank you to the staff and management of Universiti Tun Hussein Onn Malaysia for their untiring support and assistance. We acknowledge the assistance provided under the Ministry of Science, Technology and Innovation (MOSTI) grant Science Fund (S025), to support the research needed. Special appreciation to Abd Rahman J, Azhar A, Anuar N M and Roslan R for kind supports.

\section{References}

AASHTO. (2008). Classification of soil and Soil-Aggregate Mixtures for Highway Construction Purposes.

Basack, S., \& Purkayastha, R. D. (2009). Engineering properties of marine clays from the eastern coast of India. Journal of Engineering and Technology Research, 1(6), 109-114.

British Standards Institution (BSI). (1990). British Standard Methods of Test for Soils for Civil Engineering Purposes. Part 3: Chemical and electro-chemical tests. BS 1377.

Chan, C. M., Mizutani, T., Kikuchi, Y., \& Kawabata, Y. (2011). On the strength characteristics of dredged clay solidified with recycled cement. European Journal of Scientific Research, 51(4), 457-466.

Das, B.M. (2013). Fundamentals of Geotechnical Engineering (4th ed.). Canada: Cencage Learning.

Dubois, V., Abriak, N. E., Zentar, R., \& Balivy, G. (2009). The use of marine sediments as a pavement base material. Waste Management, 29, 774-782. http://dx.doi.org/10.1016/j.wasman.2008.05.004

Grubb, D. G., Chrysochoou, M., Smith, C. J., \& Malasavage, N. E. (2010). Stabilized dredged material. I: Parametric study. J. Geotech. Geoenviron. Eng., 136, 1011-1024. http://dx.doi.org/10.1061/(ASCE)GT.1943-5606.0000254

Harrington, J., \& Smith, G. (2013). Guidance on the Beneficial Use of Dredged Material in Ireland. Cork Institute of Technology.

International Labour Office. (1984). Small-scale Brick Making. Technical Memorandum No. 6, Geneva Switzerland.

Malaysia Map. (n. d.). Retrieved December 1, 2014, from http://www.malaysiavacationguide.com/malaysiamap.html

Meegoda, J. N., \& Perera, R. (2001). Ultrasound to decontaminate heavy metals in dredged sediments. Journal of Hazardous Materials, 85, 73-89. http://dx.doi.org/10.1016/S0304-3894(01)00222-9

Millrath, K., Kozlova, S., Meyer, C., \& Shimanovich, S. (2002). New approach to treating the soft clay/silt fraction of dredged material, Progress Report. Columbia University, New York, NY.

Miraoui, M., Zentar, R., \& Abriak, N. (2012). Road material basis in dredged sediment and basic oxygen furnace 
$\begin{array}{lllll}\text { steel } \quad \text { Slag. } \quad \text { Construction } & \text { and }\end{array}$ http://dx.doi.org/10.1016/j.conbuildmat.2011.11.032

Mohd Yusoff, S. A. N. (2011). Influence of different preconsolidation stress on the consolidation behavior of soft marine clay. Degree Thesis. UniversitiTun Hussein Onn Malaysia.

Mulligan, C. N., Fukue, M., \& Sato, Y. (2010). Sediments Contamination and Sustainable Remediation. CRC Press.

Mulligan, C. N., Yong, R. N., \& Gibbs, B. F. (2001). An evaluation of technologies for the heavy metal remediation of dredged sediments. Journal of Hazardous Materials, 85, 145-163. http://dx.doi.org/10.1016/S0304-3894(01)00226-6

Pebbles, V., \& Throp, S. (2001). Waste to Resource: Beneficial Use of Great Lakes Dredged Material. Great Lakes Comission.

Permanent International Association of Navigation Congress (PIANC). (2006). Environmental Risk Assessment of Dredging and Disposal Operations. Belgique: VAT BE 408-287-945.

Rao, K. D., Anusha, M., Pranav, P. R. T., \& Venkatesh, G. (2012). A laboratory study on the stabilization of marine clay using saw dust and lime. International Journal of Engineering Science and Advanced Technology, 2(4), 851-862.

Rao, K. D., Raju, G. V. R. P., Sowjanya, C., \& Rao, J. P. (2011). Laboratory studies on the properties of stabilized marine clay using from Kakinada Sea Coast, India. International Journal of Engineering Science and Technology, 3(1), 421-428.

Torres, R. J., Abessa, D. M. S., Santos, F. C., Maranho, L. A., Davanso, M. B., Nascimento, M. R. L., \& Mozeto, A. A. (2009). Effects of dredging operations on sediment quality: contaminant mobilization indredged sediments from the Port of Santos, SP, Brazil. $J$ Soils Sediments, 9, 420-432. http://dx.doi.org/10.1007/s11368-009-0121-x

US Environmental Protection Agency (USEPA) and US Army Corps of Engineers (USACE). (2004). Evaluating Environmental Effects of Dredged Material Management Alternatives-A Technical Framework. Washington: EPA 842-B-92-008.

Wan Salim, W. A., Sadikon, S. F., Salleh, S. M., Noor, N. A. M., Arshad, M. F., \& Wahid, N. (2012). Assessment of physical properties and chemical composition of Kuala Perlis dredged marine sediment as a potential brick material. 2012 IEEE Symposium on Business, Engineering and Industrial Applications. 23-26 Sept. 2012. Indonesia: IEEE. 2012. Pp. 509-512. http://dx.doi.org/10.1109/ISBEIA.2012.6422937

Winfield, L. E., \& Lee, C. R. (1999). Dredged material characterization tests for beneficial use suitability. DOER. Technical Notes Collection (TN DOER-C2), U.S. Army Engineer Research and Development Center, Vicksburg, MS.

Zentar, R., Wang, D., Abriak, N. E., Benzerzour, M., \& Chen, W. (2012). Utilization of siliceous-aluminous fly ash and cement for solidification of marine sediments. Construction and Building Materials, 35, 856-863. http://dx.doi.org/10.1016/j.conbuildmat.2012.04.024

\section{Copyrights}

Copyright for this article is retained by the author(s), with first publication rights granted to the journal.

This is an open-access article distributed under the terms and conditions of the Creative Commons Attribution license (http://creativecommons.org/licenses/by/3.0/). 